\title{
The Uses of Information Communication Technology (ICT) and The Fraud Through ICT on Orange Farmers in Wringinpitu Village
}

\author{
Nurina Adi Paramitha \\ Department of Sociology \\ Sebelas Maret University \\ Surakarta, Indonesia \\ paramitha.na@student.uns.ac.id
}

\author{
Supriyadi \\ Department of Sociology \\ Sebelas Maret University \\ Surakarta, Indonesia \\ supriyadi.sn.su@gmail.com
}

Ahmad Zuber

Department of Sociology

Sebelas Maret University

Surakarta, Indonesia

a.zuber@staff.uns.ac.id

\begin{abstract}
Information and communication technology (ICT) has changed the way of live of modern people as digital society. People living far apart can communicate without needing to be present in the same space and any information can be obtained easily. However, ICT would be useless if users didn't have capacity to use it. The research aims to determine the uses of ICT and the fraud through ICT on orange farmers in Wringinpitu Village, Banyuwangi. This research was conducted from September 2017 to April 2018. This research used qualitative method with case study approach. Data obtained through observation, documentation, and in-depth interviews. The informants were selected based on purposive sampling technique. The data validated by triangulation and analyzed by interactive model. The results show that orange farmers already have devices such as smartphones, tablets, and computers that can access the internet. Many farmers are able to purchase ICT, but they don't have capacity of how to exploit the ICT and they're not aware of fraud through ICT. Many farmers do not use ICT to access information about agribusiness and markets. They usually get information from the successful one and they just follow that information. The negative impact of ICT usually happened to orange farmers who are also traders. Many of them are victims of ICT fraud, at least once.
\end{abstract}

Keywords-capacity; information and communication technology (ICT); orange farmer; fraud victims of ICT

\section{INTRODUCTION}

The life of modern society is inseparable from the development of technology. Information and communication technology (ICT) is a form of modernization which can facilitate human life. The modern city society may already be familiar with ICT including ICT-based internet. While not all the villagers have make use of ICT-based internet. Some of the factors that cause it, among others, because of the absence of ICT facilities and human resources is still lacking.

Every human being certainly communicate, interact, and establish relationships with others every day [1]. As a social science, sociology addresses the communications network that is formed based on the social capital of related parties. Social capital highlights about the relationship, where the relationship is done through a network whose members have the same value [2, p. 1]. Digital society can get harness from ICTS to communicate with others despite living far apart. Through ICT, communication can take place without the parties must be present in the same space.

Some research in developing countries showed that ICT, particularly ICT-based internet, useful to advance people's lives especially farmers who live in rural areas. Research by Magesa, Michael, and Ko [3] in Tanzania showed that rural farmers rely on radio and mobile phone to access information about agricultural market. Research by Harmoko and Darmansyah [4] in Sambas and Singkawang, Indonesia, revealed that farmers use of television and internet to access information.

Another research, in India, farmers access information on agricultural inputs and market prices through television, radio, mobile phones, and the internet [5]. Southern Africa developed farmbook, ICT application to help farmers plan their businesses, assess productivity, and profitability of their farming enterprise [6]. Some results from that research show 
that ICT is very beneficial to the society particularly farmers to access information.

Wringinpitu developed into a modern village. In Wringinpitu and its surroundings there are many stores sell electronics and mobile phones. The villagers can easily buy the ICT. There are internet cafes and some food stalls also provided free wifi. These things make it easier for the villagers to access the internet.

Wringinpitu is a village located in Tegaldlimo district, Banyuwangi regency, East Java province, Indonesia. Banyuwangi is famous as agricultural areas. Some areas in Banyuwangi such as Purwoharjo, Bangorejo, Siliragung, and Tegaldlimo is famous for orange producer. In Tegaldlimo, one of the village known as orange-producer is Wringinpitu Village. Before plant an orange, Wringinpitu's farmers plant rice, corn, and some kind of vegetable on dry land. Around the year 2000, Wringinpitu build the well for irrigation. Orange farming began to grow after that. Orange commodity is a commodity which the price is determined by the market. Income from orange received by farmers is much higher than income from rice. Socio-economic conditions of the society in Wringinpitu increased drastically since the orange farm began.

The increased in socio-economic unfortunately not set by an increase in the capacity of human resources. Many villagers who was able to purchase ICT are not maximizing its utilization. ICT for villagers especially for farmers can be used to access agricultural information and facilitate trade. However, the low capacity of farmers make the beneficials of ICT can bring negative impact. Most farmers, especially those who also became traders had been a victim of fraud through ICT. This research aims to determine the use of ICT and the fraud through ICT that occurs on the orange farmers in Wringinpitu.

\section{LITERATURE REVIEW}

\section{A. Orange Farmer}

Many farmers in Wringinpitu are farmers with a narrow land only $\leq 0,3$ hectare, although there are also some farmers who have land up to 1 hectare. Rich farmers can rent or buy land to expand his land. Wringinpitu and the villages surrounding it are not closed-form village, so farmer can just have farmland in several locations, both in his village and other villages.

Farmers who plant an orange has increased his economy drastically. Economic improvement experienced by the Wringinpitu villagers looked from the ability of farmers of arable land may expand by hiring or purchasing farmland; farmers can build their house and buy a nice furnishings; farmers could afford to buy motorcycles and cars; farmers can buy a modern ICT such as laptop, tablet, computers, smartphones, and other; and farmers can bring their children to College.

The life of a farmer in Wringinpitu while still plant rice is very different from their life nowadays. Farmers had known rice traders, but now farmers must get acquainted with the market parties in orange agribusiness. In contrast to rice, corn, and soybeans, fruits can rotten faster and easily damaged. Farmers usually sold their oranges to get money, so the farmers no longer had time to think of advanced efforts to handle products after harvesting [7, p. 77].

The network is viewed as essential for business, because it serves as an important source of information in identifying and excavating business opportunities [2, p. 86]. Cooperation can be facilitated by norm of trust which is the social capital that is attached to the network. Norms of trust allows the occurrence of businesses trade with each other in the absence of formal procedures [2, p. 88].

The concept of social capital by Putnam is part of social life which refers to social organizations, such as trust, norms of reciprocity, and the network, which can improve the efficiency of society by facilitating coordinated actions that more effectively to achieve the common goal [2, pp. 49-51]. Social capital can be a source when the individual is not only making a bond with others but also internalize the shared values of the group [2, p. 143].

The villagers usually have a strong social capital. Orange trade in Wringinpitu can be done through communication via mobile phones. The norm of belief facilitating orange trading from Wringinpitu to big cities. Orange farmers in Wringinpitu can send a truck full of orange to market traders in big cities though without a contract or letter of agreement. This method can make it easier to trade orange, but also can be detrimental if there are parties who commit fraud.

\section{B. The Capacity of Farmers in Using ICT}

Capacity means that the ability of human resources, organizations, and societies that include knowledge, skill, and experience to take advantage of a variety of input and control the forces of nature to produce [8], [9], [10, p. 4]. Farmer capacity development is an attempt to develop knowledge and skills of farmers in farming and market agricultural output, as well as access to information and technologies regarding agriculture and its marketing.

Information needed by farmers is information about the weather; pests, diseases, and alternate responses; agricultural inputs; cultivation technology of agriculture; the market demand; and various other agricultural information. Farmers can obtain information from a variety of sources i.e. other farmers, government organizations, private organizations, farmers organizations, companies engaged in the field of agricultural inputs, journals, mass media such as newspapers, radio, television and modern ICT such as smartphones, tablets, PCs, and other to access internet [11, p. 69], [4], [5].

There still a lot of farmers in the countryside who have difficulty accessing the information agriculture. Several factors that caused trouble to access information of agriculture include:

- low level of education, such as the issue of the level of illiteracy [3], lack of interest in reading [12], farmers not active in finding information [4], and educational qualification related to ability to operate the internet and applications [6], 
- villagers meetings rarely discuss agriculture issue [3],

- newspapers not distributed in rural areas [3], [12], and

- infrastructure that hasn't been fullest [12], such as access to the electronic media and the internet depend on the availability of electricity in the rural areas [3].

Farmers can buy ICT, but they not wary about fraud occurs through ICT. Fraud can occur through phone calls, short messages service (SMS) or chat in social media. Education level of farmers is generally still low and this is an obstacle that hinders the farmers to understand information. There is many cases of online websites that contain the frauds. Perform direct communication through ICT also doesn't help much when the farmers very easy to believe and naive.

\section{METHODOLOGY}

Pre-eliminary study conducted in September 2017 by visiting the location in Wringinpitu and conduct observations. This qualitative research conducted in February to April 2018. This research uses a case study approach. Data obtained through the techniques of observation, in-depth interviews, and documentation. The informants were selected based on purposive sampling technique.

Data that has been collected is then tested with triangulation. The valid data is analyzed using the interactive model from Miles and Huberman (1992). Data analysis model of interactive flow includes the stages of data collection, data presentation, data reduction, and conclusion/ verification (Miles and Huberman, 1992).

\section{RESEARCH FINDING AND IMPLICATION}

\section{A. The Uses of (ICT) in Wringinpitu}

In Wringinpitu, there is no farmer groups that specifically deal with orange farmers. The absence of a orange farmer groups causing the slowness of the dissemination of information among farmers and the absence of mentoring expert officers. Orange farmers in Wringinpitu are self-taught farmer about how to planting, tending, harvesting, and selling oranges. The absence of mentoring of extension officers and farmers groups causing farmers should seek their own sources of information about agriculture. Many agricultural information obtained from orange farmers from other village that have had success.

The results showed that there is no news channels in the electronic media such as radio and television which specifically provides information on agriculture. Farmers in Wringinpitu capitalize on radio and television as a media of entertainment. The existence of a hot spot area not uses by the villagers to access information about agriculture. Most of the villagers who visit the stalls packed with free wifi utilizes the internet to open a wide range of social media applications via the smartphone.

Young farmers aged fifty years old and under can access the internet more easily than older farmers in over fifty years. Young farmers can easily operate the modern ICT than old farmers. In addition to the factor of age, educational factors also affect the uses of ICT among farmers in Wringinpitu. Scholars farmers who access agricultural information via the internet is able to apply the information to his farmland. While the low educated farmers didn't understand how to access agricultural information via the internet. Most low-educated farmers got information from other farmers who are considered more intelligent and highly educated.

Some farmers in Wringinpitu also worked as a fruit traders. Some traders use social media such as facebook and Blackberry Messenger (BBM) to offer the his orange commodity. They can post photos to let other know that the fruit has been harvested ready. Farmers and traders are also website to find the other traders or consumers.

\section{B. The Fraud Through ICT in Wringinpitu}

Villagers easy to believe in others. Farmers or traders frequently cheated when trading. For example, farmers or traders contacted by strangers from another village or from markets in the city. They easy to believe and give their oranges to the strangers and they wait for the money. Farmers are not use the ICT, for example to ask other farmers if the strangers is really trader or not.

Wringinpitu belongs to open village. The rules in the village is not too tight and the bond between villagers is not too strong. Social sanctions are not enforced strictly. They also do not disseminate news about the fraud to the other villagers. The issue is considered finished when fraudsters apologized or gave a reason. Usually the party that fooled not forward such fraud cases to the pathway of the law.

\section{Implication}

Orange coomodity increase farmer's income in Wringinpitu. The farmer was able to purchase ICT devices but not set by an increase in the capacity of human resources. Fraud through ICT often occurs due to farmers as villagers credulity towards others and there is no mail contract when doing the trade.

\section{REFERENCES}

[1] Eriyanto, Analisis jaringan komunikasi (strategi baru dalam penelitian ilmu komunikasi dan ilmu sosial lainnya) [Communication network analysis (new strategy in communication science and other social science research], Jakarta: Prenadamedia Group, 2014.

[2] J. Field, Social capital, London: Routledge, 2003, IEEE Transl. Modal sosial, Bantul: Kreasi Wacana, 2016.

[3] M. M. Magesa, K. Michael, and J. Ko, “Access to Agricultural market information by rural farmers in Tanzania”. Int. J. of Inform. and Commun. Technol. Res. (ICT), vol. 4, no. 7, July, 2014.

[4] Harmoko and E. Darmansyah, “Akses informasi pertanian melalui media komunikasi pada kelompok tani di Kabupaten Sambas dan Kota Singkawang [Agricultural information access through communication media on farmer groups in Sambas regency and Singkawang city]," Jurn. Komunikat., vol. 8, no. 1, May 2016.

[5] S. Mittal and M. Mehar, "How mobile phones contribute to growth of small farmers? Evidence from India”, Quarterly J. of Int. Agricult., vol. 51, no. 3, pp. 227-244, 2012. 
[6] J. S. Tata and P. E. McNamara, "Social factors that influence use of ICT in agricultural extension in Southern Africa”, Agriculture, vol. 6, no. 15, 2016.

[7] E. Pardede, "Pasca-panen dalam industri pertanian [Post harvesting in agricultural industry]”, in Menjinakkan Liberalisme (Revitalisasi Sektor Pertanian dan Kehutanan) [Taming Liberalism (Agricultural and Forestry Sector Revitalisation], A. E. Yustika, Ed., Yogyakarta: Pustaka Pelajar, 2005.

[8] UNDP, "Capacity assessment and development in a systems and strategic management context”, Technical Advisory Paper No. 3. January 1998, New York: UNDP (United Nations Development Programme), 1998.

[9] UNDP, “Capacity development: a UNDP primer”, Advocacy Primer Report, New York: UNDP (United Nations Development Programme), 2009 .
[10] M. Hopper and E. Boutrif, Strengthening national food control systems (guidelines to assess capacity building needs), Rome: FAO (Food and Agriculture Organization of The United Nations), 2006.

[11] Y. Aviati, Kompetensi kewirausahaan (teori, pengukuran dan aplikasi) [Entrepreneurs' competencies (theory, measurement, and application), Yogyakarta: Graha Ilmu, 2015.

[12] A. R. Harahap, "Pemanfaatan teknologi informasi dan komunikasi dalam pemenuhan informasi bagi rumah tangga usaha pertanian di Kecamatan Halongonan Kabupaten Padang Lawas Utara [Utilization of IT and Communication in information fulfilment for agricultural households in Halongonan District, Padang Lawas Utara Regency]," Jurn. Penelit. Komun. dan Pembang., vol. 17, no. 2, pp. 77-87, December 2016 